\title{
Multicultural Intensity: The Case of Jewish and Arab Students
}

\author{
Shmuel Shamai ${ }^{1,2}$ and Tamar Hager ${ }^{1}$ \\ ${ }^{1}$ Faculty of Social Sciences and Humanities, Tel-Hai College, Upper Galilee 12210, Israel \\ ${ }^{2}$ Golan Research Institute, University of Haifa, Kazrin 12900, Israel \\ Correspondence should be addressed to Shmuel Shamai, shamai@research.haifa.ac.il
}

Received 17 February 2012; Accepted 9 April 2012

Academic Editors: C. Dunst and B. Marlow

Copyright (C) 2012 S. Shamai and T. Hager. This is an open access article distributed under the Creative Commons Attribution License, which permits unrestricted use, distribution, and reproduction in any medium, provided the original work is properly cited.

This paper introduces a new methodology for measuring multicultural levels/intensity based on a study on attitudes towards multiculturalism conducted among college students in Israel. We developed an innovative methodological tool, "multicultural intensity," that is composed of 8 different scales: the presence of two nationalities and cultures in the college; social friendships between Arabs and Jews on campus; studying in joint classes; ways of providing assistance to students for whom Hebrew is not their mother tongue; legitimization to deal with political and social topics within the academy; classroom curriculum; multicultural tools; reality and political views toward the Arab minority in Israel. We found that Arab and Druze groups manifested more support for multicultural policies than Jewish groups. The paper suggests that "multicultural intensity" will enable researchers and practitioners to collect knowledge as to the success/failure of multicultural policies and programs among various audiences and subsequently could improve their implementation.

\section{Multiculturalism: Theoretical Framework}

Multiculturalism can be used as a mainly declarative term or as a meaningful concept that legitimizes diversity and creates social equality. The concept of multiculturalism is derived from the unsuitability of earlier ethnic concepts, namely, assimilation and the melting pot, which meant monoculturalism, and from liberal ideas about organizing the relations between the individuals and the state in a way that would defend the minorities' citizen's rights and civil rights [1-3]. Kymilicka [4, 5] characterizes liberal multiculturalism as concerned with the importance of culture for individual autonomy and recognizing ethnic and cultural diversity in a society. Taylor [6] adds the concept of recognition as an important ingredient of multiculturalism. Multiculturalism implies recognition of ethnicity as a legitimate way of grouping in the nation state. However, "legitimacy is restricted to the status of subgroups, subculture, subinstitute, and subsystem inside and under the control of the sovereign state" [7]. Legitimization and recognition do not mean equality. The concept of multiculturalism is caught between the liberal notion of full recognition of the ethnic group's rights [8] and the modern state's need for a robust common culture to create one unique nation [9]. Multiculturalism implies personal and group rights. Sometimes they may contradict each other $[10,11]$, but not necessarily.

Failure to create a multicultural state based on equality may mean that multiculturalism is just a smokescreen concealing assimilatory (or melting pot) policies. It is used to perpetuate the subordinate status of the ethnic groups by the dominant group. On the other hand, some thinkers state that while guaranteeing full (ethnic) equality, multiculturalism may atomize the society, threatening to fragment the nationstate [12].

In order to characterize the attitudes towards multiculturalism, Shamai and Paul-Binyamin [12] suggest the following classification of a "spectrum of multiculturalism" ranging from nonexistence of multiculturalism (no attempt is made to understand, recognize, or legitimize the "other" group, its culture, or symbols), declarative multiculturalism (Multiculturalism is declared by the dominant group, but as a token, and without any intention to implement it), folkloristic multiculturalism (the dominant group respects some cultural features of the minority group and legitimizes them, in addition to making multicultural declarations), symbolic multiculturalism (there is willingness to recognize important 
aspects of the ethnic minority group as part of the common culture of the entire society), to the highest degree of the existence of equal multiculturalism: this is multiculturalism that preaches equality and practices it with respect to cultural, social, political, and economic aspects of society.

The level of intensity of multiculturalism can be extracted from probing the overall beliefs, attitudes, and actual practices concerning daily living with other ethnic groups [12]. Berry [13] adds another important dimension to views on multiculturalism: the opposing interests of the dominant and the subordinate groups. The subordinate groups prefer diversity and fairness that implies recognition of their unique culture and their special needs. Moreover, in a multicultural society, the subordinate group will get the same level of support and understanding as the dominant group. However, the tendency of the dominant group is to apply universal standards and requirements, based on their own culture, mainly in the important institutions of the state such as education, health, law, and security. In other words, the inferior part of the society ("ethnic groups") would prefer "equal multiculturalism" [8], while the highest/dominant sector would prefer a low level of intensity of multiculturalism. In a stratified society implementation of multiculturalism means that the dominant society may lose some resources (such as symbolic, cultural, political and economic resources) and the subordinate group may gain these resources. Thus, the subordinate group is expected to advocate multiculturalism more intensively than the dominant group. Kymilicka [8] describes it: "The real change has been in people consciousness. Members of historically subordinated groups today demand equality, and demand it as a right. They believe they are entitled to equality, and demand it now, not in some indefinite future" (page 8).

\section{Multicultural Intensity}

Following research of the attitudes of Jewish and Arab students towards multiculturalism throughout their studies in one institution for higher education in Israel [14], we created a tool for measuring the level of participants' multiculturalism-multicultural intensity. The tool is composed of eight predicators, which are considered to be aspects or dimensions of multicultural thinking, as revealed in the literature on multicultural theory. This has already been conceptualized by Shamai and Paul-Binyamin's research [12] done in two colleges in Israel and various additions in a following research [14] conducted in an additional college.

The tool of multicultural intensity is composed of the following predicators:

(i) the presence of two nationalities and cultures in an institution, for example, a college, a school, and so forth,

(ii) social friendships/estrangement between individuals belonging to the minority and the dominant group,

(iii) gains/losses from cooperation or joint projects (learning in the same class), (iv) support for the minority or subordinate group by the dominant group (mentoring program, etc.),

(v) legitimization/delegitimization in dealing with political and social topics within the institution,

(vi) sharing knowledge about the culture and history of the different groups,

(vii) learning multicultural tools and information on multicultural reality (dialogue, etc.),

(viii) political views toward the minority.

Employing this tool in our test case-the attitudes of Israeli students to multiculturalism-provides evidence for Kymilicka's statement that minorities support multicultural policies and programs more than dominant groups. However, to understand the use of the tool in the present testcase and the relevance of Kymilicka's assertion to Israel in general and to the Israeli academia, where this research was conducted, in particular, this paper probed the attitudes of two groups in the Israeli society: the dominant Jewish groups and the subordinate Arab groups who are Israel's largest minority. The sociopolitical state of affairs among these two groups is even more complex due to the Israeli-Arab conflict. In order to understand the status of Arabs and Jews in the Israeli academia, we must understand off-campus realities.

\section{Jews and Arabs in Israel}

Israel is characterized by its many cultures. Scholars who have written about multiculturalism in Israel $[15,16]$ have agreed that Israel has many cultures, without, however having a multicultural ideology or practices. Israeli society is composed of multiple ethnic groups, resulting in encounters between Russian immigrants and native Israelis, Sephardim (Eastern Jews) and Ashkenazim (Western Jews), secular, orthodox, and ultraorthodox Jews, and also between Arabsfrom several groups, sometimes congruent: Christians, Muslims, Druze, Alawis, and Bedouins-and Jews. The relations between Arabs and Jews are the most difficult and sensitive due to the Arab-Jewish conflict. Apart from differences in religion, language, and cultural characteristics, they differ in their national identities (Arabs, although they are citizens of Israel, often define themselves as Palestinians), and the Israeli-Palestinian conflict influences their relations to Israel as a Jewish democratic state [17].

According to Smooha [18], the relationship between Arabs and Jews in Israel is affected by several major factors

(i) The attachment of the Israeli Arabs to the Arab world and the Palestinian people disturbs the Jews' feelings regarding Israel's security. Seeing the Arab minority as part of the Arab world, which at times expresses hostility towards the State of Israel, they may see them as the enemy.

(ii) Islam's cultural and religious awakening also influences the Arab attitude to the state and to the Jews.

(iii) Zionist-Jewish ideology creates inequality between the Jews and the Arabs. 
(iv) Democracy: Israel is committed to a democratic regime for all its citizens, and this underlies the demand for equality.

(v) The Jewish majority enjoys overall predominance. The Arabs find themselves a minority in a state that the Jews have built and dominate.

The Druze are a peculiar group in the Israeli society. They speak Arabic, share Arab culture, but they have their own religion, which was founded in the eleventh century in Egypt and developed from Islam. The Jewish establishment treats the Druze differently than Muslim and Christian Arabs. Druze leaders have sworn allegiance to the State of Israel, giving them some privileges over the other Arab minorities [19]. The Druze serve in the Israeli army (service is compulsory for them, as for the Jews), and they are pedagogically and administratively separated from the Arab educational system. Due to the Israeli-Arab conflict and the fact that Druze both retain Arab culture and serve in the Israeli army, their own identity has become more complex than other ethnic or religious groups.

\section{Methodology}

The research question that guided this study was: what differences with regard to attitudes toward multiculturalism exist among female and male students belonging to different national and religious groups, practicing different levels of religiosity?

Research Population. Tel-Hai College has 3,000 students; 400 of them are Arabs (13\%) and all the others are Jews. Fortysix percent of the student body are Galilee residents, $47 \%$ come from central Israel (Tel Aviv and Jerusalem areas) and an additional $7 \%$ come from the south of the country.

Participants. This study was conducted in 2008-2009 among 681 students of Tel-Hai College in the Galilee, the northern periphery of Israel. The students who answered our questionnaire were randomly selected, in their first or third year of study for a bachelor's degree and represented all academic departments. They varied in their ethnicity and their faiths, although the majority (87\%) were Israelis and/or Jewish.

Out of 24 definitions of national identity that were received from the students, we have chosen to focus on the five most common (which cover $90.1 \%$ of the sample: three Jewish (Jewish, Jewish-Israeli, and Israeli) and two of minority groups (Arab and Druze). The average age of participants was 26. The sample framework appears in Table 1.

\section{Measures}

Based on the Shamai and Paul-Binyamin [12] questionnaire, we included 88 Likert items $(1=$ totally disagree to $5=$ very much agree) with eight distinct scales in Hebrew and in Arabic. Added to the original questionnaire were new clusters of questions concerning the college's curriculum and regarding positions towards social and political issues inside and outside the college. The units were divided into eight
TABLE 1: The sample framework-descriptive statistics.

\begin{tabular}{|c|c|c|c|}
\hline Variable & Category & Number & $\%$ \\
\hline \multirow{2}{*}{ Year of study } & $1 \mathrm{st}$ & 355 & 55.4 \\
\hline & $3 \mathrm{rd}$ & 286 & 44.6 \\
\hline \multirow{9}{*}{ Academic department } & Economics & 60 & 9.4 \\
\hline & Nutrition science & 93 & 14.5 \\
\hline & $\begin{array}{l}\text { Environmental sciences } \\
\text { and biotechnology }\end{array}$ & 50 & 7.8 \\
\hline & Computer science & 39 & 6.1 \\
\hline & Social work & 140 & 21.8 \\
\hline & Education & 112 & 17.5 \\
\hline & Multidisciplinary studies & 37 & 5.8 \\
\hline & $\begin{array}{c}\text { Education and } \\
\text { multidisciplinary studies }\end{array}$ & 41 & 6.4 \\
\hline & Missing values & 69 & 10.8 \\
\hline \multirow{3}{*}{ Gender } & Male & 151 & 23.6 \\
\hline & Female & 477 & 74.4 \\
\hline & Missing values & 13 & 2.0 \\
\hline \multirow{6}{*}{ Nationality and faith } & Jewish & 278 & 43.4 \\
\hline & Israeli-Jewish & 192 & 30 \\
\hline & Israeli & 83 & 12.9 \\
\hline & Druze & 27 & 4.2 \\
\hline & Arab & 55 & 8.6 \\
\hline & Missing values & 6 & 0.9 \\
\hline \multirow{3}{*}{ Level of religiosity } & Secular & 430 & 67.1 \\
\hline & Traditional & 134 & 20.9 \\
\hline & Religious & 50 & 7.8 \\
\hline
\end{tabular}

topics (for the full details of questions and answers, see [20]), and a scale index was constructed from each topic.

\subsection{Relations between Arabs and Jews}

(i) The presence of two nationalities and cultures in the college (10 items). For example: signs in Arabic should be set up all over the campus, or in different classes (such as arts, literature, sociology, history, and philosophy) presentation of the Arab/Palestinian point of view should be increased or: Arab holidays should be recognized and $\backslash$ celebrated on campus as are the Jewish holidays.

Cronbach's Alpha yielded internal consistency of 0.91 . $($ Median $=3.30)$.

(ii) Social friendships between Arabs and Jews on campus (15 items). For example, I have Arab/Jewish friends, I'm ready to live with Arab students in the college dormitory or: I'm interested in Jewish-Arab student meetings.

Cronbach's Alpha yielded internal consistency of 0.83 . $($ Median $=3.20)$. 
(iii) Studying in joint classes (6 items). For example, I prefer to study in mixed classes of Jewish and Arab, or in classes that Arabs and Jewish students attend there are intellectually in higher level students.

Cronbach's Alpha yielded internal consistency of 0.74 . (Median $=3.33$ ).

(iv) Ways of providing assistance to students for whom Hebrew is not their mother tongue (12 items). For example, a learning support center for Arab students should be established, or having an Arab librarian in the library is a good idea and s/he can give support to the Arab-speaking students.

Cronbach's Alpha yielded internal consistency of 0.92 . $($ Median $=3.42)$.

\subsection{General Views}

(i) Legitimization for dealing with political and social topics within the academy (10 items). For example, the academy should initiate and support activities of human rights, or the academia should focus on theoretical studies.

Cronbach's Alpha yielded internal consistency of 0.82 . (Median $=3.30)$.

(ii) Classroom curriculum (8 items). For example, the studies expose me to many different aspects and viewpoints of different groups in Israeli society, or in at least one course that I studied there was a discussion about Arab culture.

Cronbach's Alpha yielded internal consistency of 0.90 . (Median $=2.38$ ).

(iii) Multicultural tools and reality (16 items). For example, I expect that the curriculum will give me tools to be able to carry out multicultural dialog based on equality or I would like to study about multiculturalism and its importance to democracy.

Cronbach's Alpha yielded internal consistency of 0.94 . (Median $=3.50)$.

(iv) Political views toward the Arab minority in Israel (11 items). For example, the State of Israel must insist on equal rights for all of its citizens, Jews and Arabs, or Arab citizens should not be allowed to be elected to the Israeli parliament.

Cronbach's Alpha yielded internal consistency of 0.87 . $($ Median $=3.45)$.

5.3. Procedure. The questionnaire was distributed in the classes between December 2008 and May 2009. The time frame during which we collected the data partially overlapped the Gaza War (December and January), when the political debate on this particular issue and the IsraeliPalestinian conflict in general was very explosive; the students' opinions on this matter were reflected in their responses. In some cases the students were reluctant to fill out the items and showed clear reservations regarding the issues dealt with in the questionnaire. However, only three students refused to answer the questionnaire altogether.

In order to check the influence of our background variables (i.e., gender, academic department, nationality and religious faiths, and the extent of religiosity) on the dependent variables (i.e., units $1-4$ and $6-9$ ), we used standard $t$-tests and one-way ANOVA with a post hoc Bonferroni test.

\section{Results}

The eight above-mentioned indexes based on these eight scales were probed in regard to nationality and religious variable. Analysis of variance (ANOVA) was calculated, to examine the differences among the groups. Post hoc Bonferroni test was calculated (see Table 2).

In six out of eight indexes considering the level of multiculturalism, the group that mainly advocated multiculturalism was the Arabs, then the Druze, and the Jewish majority favored it less.

From the eight scales we constructed a new variable that is expected to manifest the level of intensity of multiculturalism. The new variable "multiculturalism intensity" counted the number of times that the student scored higher than the median. If each of the students' eight different scores was higher than the median for the specific scale, his/her score was eight, and if none, the score was zero.

Results indicated that 148 students scored zero (21.7\%), and 81 respondents scored eight (11.9\%). Cronbach's Alpha yielded internal consistency of 0.84 . To simplify this scale a new scale was developed: the zero to eight results were categorized to four groups: $0-2,2.01$ to $4,4.1$ to 6 and 7.01 to 8 . The new variable, "categories of multicultural intensity," was probed regarding nationality and religion, as shown in Table 3.

Forty-five percent of the Jewish students classified are ranked in the two lowest categories, compared to nine percent of the non-Jews. However, more than a third (36\%) of the Jewish students and two-thirds (71\%) of the Arabs are in the four highest categories (5-8). Namely, although the rate of Arabs supporting multiculturalism is significantly higher, the rate of Jews who show some interest in advocating multiculturalism is not negligible.

However, the results point to noticeable differences among the examined groups. Arabs are the most multiculturally oriented; Druze support of this agenda is less significant, while Jews are the least multiculturally oriented. According to analysis of variance the differences were statistically significant (df: 662, 4; $F=18.08, P=0.000$ ).

The relations between religiosity and nationality were also examined. Because of the small subgroups, nationality was organized into two groups, Jews and Arabs, ignoring the differences among different Arab and Jewish groups. The results are shown in Table 4 for Jews and for Arabs.

The different patterns are striking. Among the Jewish students religion has an important effect on their views of multiculturalism: the more religious they are the less sympathetic they are to the concept of multiculturalism. In the case of the Arab students, there is no connection between support of multicultural ideas and the level of religiously. Regarding the Jews, according to analysis of variance, the differences were statistically significant (df: 549,$2 ; F=17.84, P=$ 0.000 ). Regarding the Arabs, according to analysis of variance the differences were not statistically significant (df: 2,$90 ; F=$ $0.34, P=0.712$ ). Because of the small numbers of the Arabs who define themselves as religious, a nonparametric chisquare test was conducted $\left(\chi^{2}=.4 .09, \mathrm{df}=6 ; P=0.66\right)$ and again the differences were not significant. 
TABLE 2: Level of "multicultural intensity" according to religion and national identity.

\begin{tabular}{|c|c|c|c|c|c|c|c|}
\hline & \multicolumn{2}{|c|}{ ANOVA } & \multicolumn{4}{|c|}{ Descriptive statistics of nationality and religion } & \multirow{2}{*}{$\begin{array}{l}\text { Tests of differences between } \\
\text { nations and religions } \\
\text { POST-HOC (sig. < } 0.01 \text { ) }\end{array}$} \\
\hline & $F$ & $\begin{array}{l}\text { Sig. } \\
(<0.005)\end{array}$ & $\begin{array}{l}\text { Nationality } \\
\text { and religion }\end{array}$ & $N$ & Mean & $\begin{array}{c}\text { Std. } \\
\text { deviation }\end{array}$ & \\
\hline \multirow{5}{*}{$\begin{array}{l}\text { Presence of two nations } \\
\text { and cultures in the college }\end{array}$} & \multirow{5}{*}{19.573} & \multirow{5}{*}{0.000} & Jew & 278 & 2.92 & 1.018 & Jew-Israeli, Israeli, Druze, Arab \\
\hline & & & Jew-Israeli & 192 & 3.24 & 1.049 & Jew, Arab \\
\hline & & & Israeli & 83 & 3.33 & 0.952 & Jew, Arab \\
\hline & & & Druze & 26 & 3.89 & 0.847 & Jew \\
\hline & & & Arab & 55 & 4.09 & 0.919 & Jew, Jew-Israeli, Israeli \\
\hline \multirow{5}{*}{$\begin{array}{l}\text { Relationship between Arab } \\
\text { and Jewish students in the } \\
\text { college }\end{array}$} & \multirow{5}{*}{7.933} & \multirow{5}{*}{0.000} & Jew & 277 & 3.05 & 0.819 & Arab \\
\hline & & & Jew-Israeli & 192 & 3.28 & 0.757 & Arab \\
\hline & & & Israeli & 82 & 3.33 & 0.719 & - \\
\hline & & & Druze & 27 & 3.43 & 0.583 & - \\
\hline & & & Arab & 55 & 3.59 & 0.496 & Jew, Jew-Israeli \\
\hline \multirow{5}{*}{$\begin{array}{l}\text { Relations of the state } \\
\text { toward Arab citizens }\end{array}$} & \multirow{5}{*}{20.382} & \multirow{5}{*}{0.000} & Jew & 276 & 3.14 & 0.883 & Israeli, Druze, Arab \\
\hline & & & Jew-Israeli & 189 & 3.37 & 0.885 & Arab, Druze \\
\hline & & & Israeli & 80 & 3.67 & 0.798 & Jew, Arab \\
\hline & & & Druze & 27 & 3.88 & 0.649 & Jew, Jew-Israeli \\
\hline & & & Arab & 54 & 4.12 & 0.576 & Jew, Jew-Israeli, Israeli \\
\hline \multirow{5}{*}{$\begin{array}{l}\text { Reality of studies in mixed } \\
\text { classes }\end{array}$} & \multirow{5}{*}{15.242} & \multirow{5}{*}{0.000} & Jew & 269 & 3.13 & 0.883 & Israeli, Druze, Arab \\
\hline & & & Jew-Israeli & 187 & 3.24 & 0.835 & Arab, Druze \\
\hline & & & Israeli & 79 & 3.43 & 0.730 & Arab \\
\hline & & & Druze & 27 & 3.82 & 0.463 & Jew, Jew-Israeli \\
\hline & & & Arab & 54 & 3.97 & 0.688 & Jew, Jew-Israeli, Israeli \\
\hline \multirow{5}{*}{$\begin{array}{l}\text { Need to help } \\
\text { non-Hebrew-speaking } \\
\text { students }\end{array}$} & \multirow{5}{*}{17.694} & \multirow{5}{*}{0.000} & Jew & 264 & 3.09 & 1.001 & Israeli, Druze, Arab \\
\hline & & & Jew-Israeli & 186 & 3.33 & 0.918 & Arab, Druze \\
\hline & & & Israeli & 80 & 3.52 & 0.801 & Jew, Arab \\
\hline & & & Druze & 27 & 4.03 & 0.779 & Jew, Jew-Israeli \\
\hline & & & Arab & 52 & 4.09 & 0.794 & Jew, Jew-Israeli, Israeli \\
\hline \multirow{5}{*}{$\begin{array}{l}\text { Representation of } \\
\text { social-political issues in the } \\
\text { academy }\end{array}$} & & & Jew & 260 & 3.11 & 0.833 & Israeli \\
\hline & & & Jew-Israeli & 183 & 3.36 & 0.813 & - \\
\hline & & & Israeli & 77 & 3.52 & 0.764 & Jew \\
\hline & & & Druze & 26 & 3.27 & 0.758 & - \\
\hline & & & Arab & 52 & 3.44 & 0.704 & - \\
\hline \multirow{5}{*}{ Classroom curriculum } & \multirow{5}{*}{2.949} & \multirow{5}{*}{0.020} & Jew & 252 & 2.26 & 1.12 & Israeli \\
\hline & & & Jew-Israeli & 181 & 2.44 & 1.24 & - \\
\hline & & & Israeli & 76 & 2.69 & 1.16 & Jew \\
\hline & & & Druze & 28 & 2.72 & 0.85 & - \\
\hline & & & Arab & 56 & 2.42 & 1.07 & - \\
\hline \multirow{5}{*}{$\begin{array}{l}\text { Existence of } \\
\text { multiculturalism }\end{array}$} & & & Jew & 247 & 3.28 & 1.054 & Jew-Israeli, Israeli, Arab \\
\hline & & & Jew-Israeli & 182 & 3.67 & 0.998 & Jew \\
\hline & & & Israeli & 77 & 3.78 & 0.814 & Jew \\
\hline & & & Druze & 25 & 3.77 & 0.756 & - \\
\hline & & & Arab & 51 & 3.90 & 0.884 & Jew \\
\hline
\end{tabular}


TABLE 3: Frequencies of categories of "multicultural intensity" according to nationality and religion.

\begin{tabular}{lccccccc}
\hline & $1-2$ & $3-4$ & $5-6$ & $7-8$ & Mean & S.D. & Total \\
\hline Jew & 155 & 44 & 40 & 41 & 2.77 & 2.66 & 290 \\
Jew-Israeli & 80 & 38 & 40 & 42 & 3.61 & 2.85 & 200 \\
Israeli & 24 & 19 & 21 & 20 & 4.13 & 2.63 & 84 \\
Druze & 3 & 7 & 12 & 11 & 5.20 & 2.07 & 33 \\
Arab & 5 & 12 & 23 & 20 & 5.41 & 2.77 & 60 \\
\hline Total & 267 & 130 & 136 & 134 & & 667 \\
\hline
\end{tabular}

TABLE 4: Level of "multicultural intensity" according to nationality and religion-analysis of variance.

\begin{tabular}{lcccc}
\hline & $N$ & Mean & S.D. & F \\
\hline Jews & & & & \\
$\quad$ Secular & 416 & 3.61 & 2.75 & 17.84 \\
$\quad$ Traditional & 96 & 2.53 & 2.76 & 0.000 \\
$\quad$ Religious & 40 & 1.28 & 1.62 & 0.34 \\
\hline Arabs & & & 2.31 & 0.712 \\
$\quad$ Secular & 34 & 5.32 & 2.03 & 1.57 \\
$\quad$ Traditional & 48 & 5.69 & & \\
$\quad$ Religious & 11 & 5.69 & & \\
\hline
\end{tabular}

TABLE 5: Intensity of multiculturalism according to proximity to Jewish settlers in the West Bank.

\begin{tabular}{lccc}
\hline & $N$ & Mean & S.D. \\
\hline Extremely close & 100 & 2.64 & 2.80 \\
Very close & 65 & 3.42 & 2.82 \\
Close & 95 & 3.40 & 2.67 \\
Not close & 80 & 3.61 & 2.66 \\
Not close at all & 68 & 4.29 & 2.47 \\
Very much not close & 152 & 4.40 & 2.77 \\
\hline
\end{tabular}

"Multiculturalism intensity" was also probed regarding political views. These were examined regarding the question "How close do you feel towards Jewish settlers in the West Bank." The closer the respondents feel towards the settlers, the more they are regarded in Israeli politics as "right-wing oriented," and the less close they feel towards them, the more they are regarded as "left-wing oriented." The question scale was from $1=$ very close to $6=$ not close at all. The results appear in Table 5 .

The results are clear: the more the respondents tend to the "right," the less sympathetic they are to multicultural ideas. According to analysis of variance the differences were statistically significant (df: 554,$5 ; F=6.12, P=$ $0.000)$. Gender differences were also found to be significant. However, when the two groups were analyzed separately, the difference was significant only among the Jews, but not among the Arabs, as indicated in Table 6.

The study also probed private versus group rights, as shown in Table 7, in which a comparison was made of statements with similar content (i.e., "Jews and Arabs can live peacefully in the State of Israel" as public sphere versus "I prefer to study in mixed (Jews and Arabs) classes" as private sphere). These results manifest that both Arabs and Jews support private rights more than public rights.

\section{Discussion}

Usually multiculturalism is referred to as a vague and/or holistic phenomenon. This study intends to elaborate on two major aspects of the research conducted on multiculturalism over the last decades. Rather than surveying multiculturalism as an overall cultural notion, this paper represents it as a multifaceted phenomenon, creating a methodological tool that examines and measures it accordingly. Multiculturalism, this study suggests, is composed of a variety of features that can be represented and described by a single figure. The eight scales were

(1) the presence of two nationalities and cultures in the college,

(2) social friendships between Arabs and Jews on campus,

(3) studying in joint classes,

(4) ways of providing assistance to students for whom Hebrew is not their mother tongue,

(5) legitimization to deal with political and social topics within the academy,

(6) classroom curriculum,

(7) multicultural tools and reality,

(8) political views toward the Arab minority in Israel.

These scales describe the different parameters that make up multiculturalism. They include general views on the shared public sphere, minority rights, and their place in 
TABLE 6: Intensity of multiculturalism according to gender.

\begin{tabular}{llllll}
\hline & $N$ & Mean & S.D. & $t$ & $P$ \\
\hline All & & & & & \\
$\quad$ Males & 168 & 3.16 & 2.74 & -2.31 & 0.021 \\
$\quad$ Females & 499 & 3.73 & 2.80 & & 0.011 \\
\hline Jews & & & & -2.55 & N.S. \\
$\quad$ Males & 139 & 2.76 & 2.67 & & -0.59 \\
$\quad$ Females & 422 & 2.78 & & & \\
\hline Arabs & & & 2.78 & & \\
$\quad$ Males & 28 & 5.24 & 2.15 & & \\
$\quad$ Females & 73 & 5.52 & & & \\
\hline
\end{tabular}

TABLE 7: Intensity of multiculturalism—private rights and group rights paired ( $t$-test).

\begin{tabular}{|c|c|c|c|c|c|}
\hline & $N$ & Mean & S.D. & Paired $t$-test & Sig \\
\hline \multicolumn{6}{|l|}{ Jews (1st pair) } \\
\hline Jews and Arabs can live peacefully in the State of Israel & \multirow{2}{*}{540} & 2.67 & 1.46 & \multirow{2}{*}{-11.17} & \multirow{2}{*}{0} \\
\hline I prefer to study in mixed (Jews and Arabs) classes & & 3.37 & 1.32 & & \\
\hline \multicolumn{6}{|l|}{ Jews (2nd pair) } \\
\hline The Sate of Israel must make sure that there is equality among all its citizens & \multirow{2}{*}{552} & 3.33 & 1.28 & \multirow{2}{*}{-6.76} & \multirow{2}{*}{0} \\
\hline I'm ready to reside with an Arab/Jew partner in the students' residence & & 3.71 & 1.32 & & \\
\hline \multicolumn{6}{|l|}{ Arabs (1st pair) } \\
\hline Jews and Arabs can live peacefully in the State of Israel & \multirow{2}{*}{98} & 3.53 & 1.47 & \multirow{2}{*}{-3.01} & \multirow{2}{*}{0.003} \\
\hline I prefer to study in mixed (Jews and Arabs) classes & & 4.1 & 1.15 & & \\
\hline \multicolumn{6}{|l|}{ Arabs (2nd pair) } \\
\hline The State of Israel needs to make sure that there is equality among all its citizens & \multirow{2}{*}{100} & 4.13 & 1.08 & \multirow{2}{*}{-4.17} & \multirow{2}{*}{0} \\
\hline I'm ready to reside with an Arab/Jewish partner in the student residence & & 4.69 & 0.79 & & \\
\hline
\end{tabular}

campus and general views on the role of academia when dealing with (sensitive) political $\backslash$ social relationships/issues. This scale also includes actual practices of Jews' and Arabs' joint learning and actual implementation of multiculturalism in the classroom.

We assume that developing a model that describes the multidimensional character of multiculturalism by using a "multicultural intensity scale" may increase understanding of the attitudes toward multiculturalism. Moreover, such a model will enable researchers and practitioners to implement multicultural programs and policies more effectively.

However, this research also makes an empirical contribution to the research of multiculturalism. The most consistent empirical result is that Arab groups manifested more support for multicultural policies than Jewish groups. What particularly determines the positions of the students towards adopting multiculturalism is their national-cultural origin. The students who define themselves as Jews manifested a lower level of support for multiculturalism. That coincides with the finding that religious Jews demonstrated the lowest level of support for multicultural beliefs. Arab students manifest far more willingness to adopt multicultural attitudes. This finding confirms Kymilicka's notion that the subordinate group in every society tends to support multicultural policies. The Druze, who enjoy more privileges in the Israeli state, behave as a "middle group," that is, they support multiculturalism more than Jews but less than Arabs. The students who defined themselves as "Israelis" and the secular Jews tend to accept multicultural ideas. Similarly, the "right-wing" students (who are traditionally more religious) again are less open to multiculturalism.

The study also reveals that gender has some influence on feelings about multicultural beliefs: females' views on multiculturalism are more positive and supportive (similar findings in [21]).

Regarding the Arab-Jewish relations, the study reveals that despite the difficulty of living in the shadow of the conflict, mutual respect was maintained and there was a declared belief that values such as humanism, equal rights, and human rights must be safeguarded. The Arabs, as a subordinate group, have more to gain and thus more motivation-as expected-to try to create an atmosphere of openness in a multicultural framework. They see their benefits from such reality much more clearly. The dominant Jewish group has 
only moderate motivation. Most members of the group do not suffer under the existing institutional practices and social realities; thus, they do not tend to act to change them. However humanist views lead some of them (secular Jews and mainly women, as the study shows) to understand the unfairness of the situation and maybe even to see the benefits of closing the gap between Jews and non-Jews, and thus they support a cultural change.

According to the research, it seems that most Jewish students support "declarative multiculturalism" or "folkloristic multiculturalism" and recoil from "symbolic multiculturalism." Declared and folkloristic multiculturalism can be seen, for example, in the fact that most students feel that knowledge about Arab culture should be more widely included in the curriculum, that expression and recognition of Arab culture should be given on campus over and above class time, and even that school vacations should be given on Muslim and on Christian holidays. But Jewish support weakens when Jews are questioned about "symbolic multiculturalism," which would mean approval for visible Arab national and religious symbols on campus. Arab students universally support campus visibility for such symbols, and this expresses their aspiration for a campus that includes the signposts of their culture.

Interestingly, both Arabs and Jews support private rights more than the public rights. This may mean that there is hope for potential dialogue on the personal level, as most of their lives both sides have grown up separately. This could add another dimension to the above-mentioned results.

In the Israeli political situation, the fact that Jewish students support personal dialogue with Arab students and manifest positive views toward multiculturalism ("declarative" and/or "folkloristic multiculturalism") may surprise us. According to Smooha [18] the attachments of the Israeli Arabs to the Arab world and the Palestinian people disturb Jews' feelings towards them, and they are at times seen as the enemy. Nevertheless, despite such a sensitive starting point, the Jewish students do not reject the concept of multiculturalism. In a reality of continuous relationships and cohabitation on campus, to a certain extent they tend to embrace or at least openly support some cultural, human, and civil rights for Arab students.

It seems that the reasons that determine the attitudes toward multiculturalism are a mix of personal and social statuses or achieved and ascribed statuses. Nationality (Jews versus Arabs) and gender are ascribed statuses, while religiosity, course of studies, and political views are achieved statuses. Therefore, the personal level of multicultural intensity is perceived as a mix of personal and collective interests, and views and beliefs concerning the gains and losses from multiculturalism.

Maybe the readiness to recognize the private more than the public sphere derives from general support of human rights, which are perceived as the privilege of any human being no matter what is his/her nationality, religion, and race while the support of collective/public rights has been less assimilated in a situation of continuous national conflict. To answer this question further research is needed.

\section{Acknowledgment}

We thank Galileo Foundation for its generous support to this study.

\section{References}

[1] R. M. Smith, "The constitution and autonomy," Texas Law Review, vol. 60, pp. 175-205, 1982.

[2] A. Ingram, A Political Theory of Rights, Clarendon Press, Oxford, NY, USA, 1994.

[3] R. D. Grillo, Pluralism and the Politics of Difference: State, Culture and Ethnicity in Comparative Perspective, Clarendon Press, Oxford, NY, USA, 1998.

[4] W. Kymilicka, Liberalism, Community and Culture, Oxford University Press, Oxford, UK, 1989.

[5] W. Kymilicka, Multicultural Citizenship, Clarendon Press, Oxford, NY, USA, 1995.

[6] C. Taylor, Multiculturalism, Examining: The Politics of Recognition, Princeton University Press, Princeton, NJ, USA, 1994.

[7] S. Shamai, "Critical theory of education and ethnicity: the case study of the Toronto Jewish community," Journal of Education, vol. 169, no. 2, pp. 89-114, 1987.

[8] W. Kymilicka, "Multiculturalism and minority rights: West and East," Journal on Ethnopolitics and Minority Issues in Europe, vol. 4, pp. 1-25, 2002.

[9] M. Al-Haj, "Multiculturalism in deeply divided societies: the Israeli case," International Journal of Intercultural Relations, vol. 26, no. 2, pp. 169-183, 2002.

[10] S. M. Okin, "Is Multiculturalism Bad for Women?" in Is Multiculturalism Bad for Women? S. Okin, Ed., pp. 7-27, Princeton University Press, Princeton, NJ, USA, 1998.

[11] W. Kymilicka, "Liberal Complacencies: A response to Susan Okin," BostonBook Review, 1999, http://www.bostonreview .net/BR22.5/kymlicka.html.

[12] S. Shamai and I. Paul-Binyamin, "A model of intensity of multicultural relations: the case of teacher training colleges in Israel," Race Ethnicity and Education, vol. 7, no. 4, pp. 422-436, 2004.

[13] J. Berry, "From the melting pot to cultural pluralism: implications for higher education and training of human service professionals," in Cultural Diversity as a Challenge to Human Services, E. Leshem and D. Roer-Strier, Eds., pp. 113-123, Magnes, Jerusalem, Palestine, 2003.

[14] Hager, S. Shamai, R. Garriba, T. Sivan, T. Saba, and N. Shay, "Multiculturalism on campus in the shadow of Jewish-Arab conflict: Jewish and Arab students' attitudes," in Student Attitudes, L. Zysberg, Ed., pp. 56-84, Nova Publishers, Haugpegue, NY, USA, 2011.

[15] B. Kimmerling, "The New Israelis: multiple cultures without multiculturalism," Alpaym, vol. 16, pp. 263-308, 1998.

[16] Y. Tamir, "Two concepts of multiculturalism," in Multiculturalism in a Democratic Jewish State, M. Mautner, A. Sagi, and R. Shamir, Eds., pp. 79-92, Ramot, Tel Aviv, Palestine, 1998.

[17] N. Rouhana, "Israel and its Arab citizens: predicaments in the relationship between ethnic states and ethnonational minorities," Third World Quarterly, vol. 19, no. 2, pp. 277-296, 1998.

[18] S. Smooha, "The Arab-Jewish relationship in Israel as a Jewish and democratic state," in Trends in Israeli Society, E. Ya'ar and Z. Shavit, Eds., pp. 231-363, The Open University of Israel, Tel Aviv, Palestine, 2001.

[19] R. Halabi, Citizen of Equal Duties: Druze Identity and the Jewish State, Hakibbutz Hameuchad, Tel Aviv, Palestine, 2006. 
[20] T. Hager, S. Shamai, R. Garribba, T. Sivan, T. Saba, and N. Shay, "Attitudes of students to multiculturalism at Tel-Hai College: Research report," Center for Peace and Democracy at Tel Hai College, 2010.

[21] Z. Ilatov and S. Shamai, "Israeli Students' Attitudes Towards Children Immigrants From Russia," The Journal of Culture \& Society, vol. 4, pp. 77-93, 1996. 

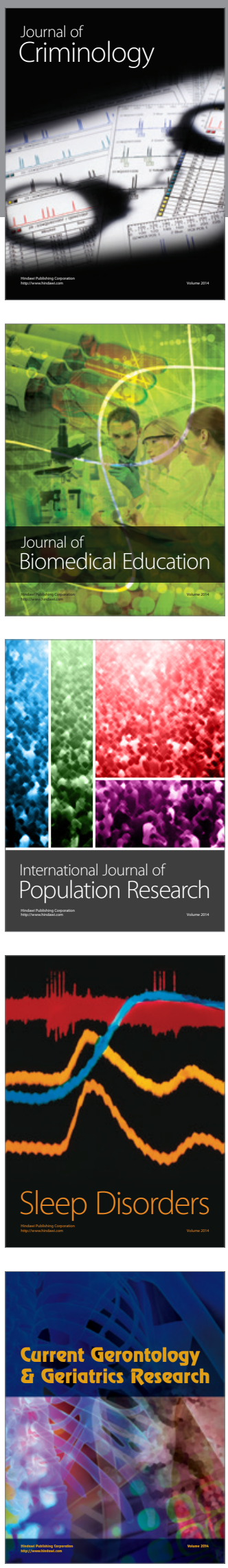
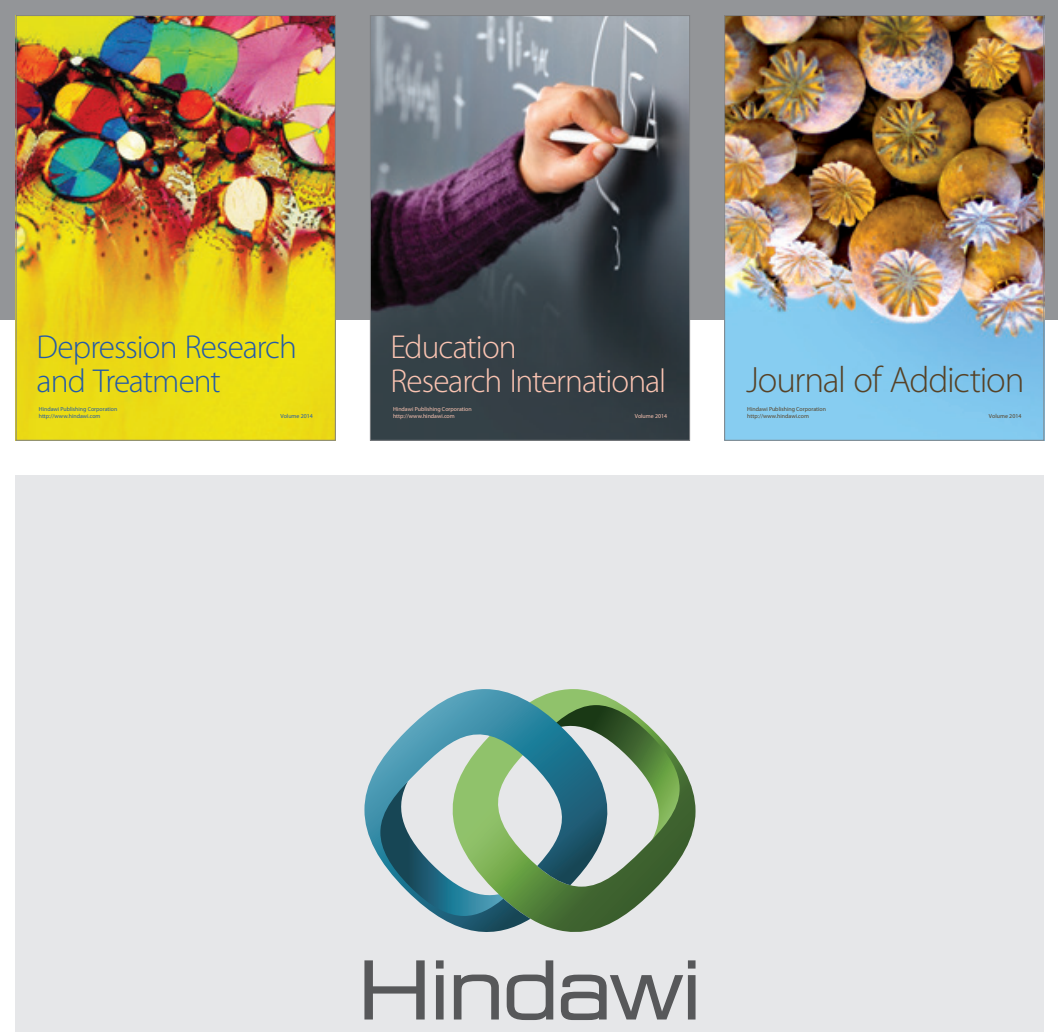

Submit your manuscripts at

http://www.hindawi.com

Child Development Research
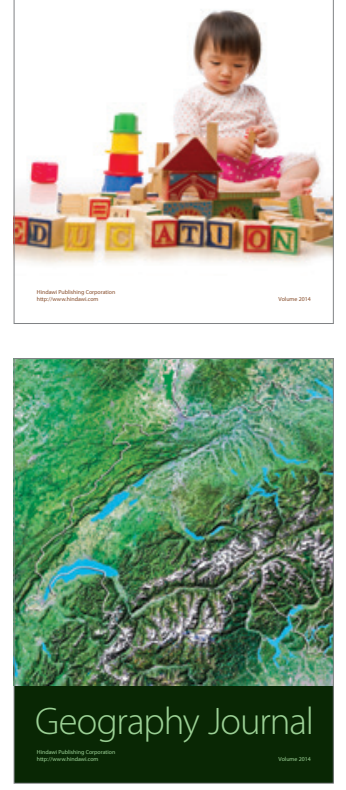

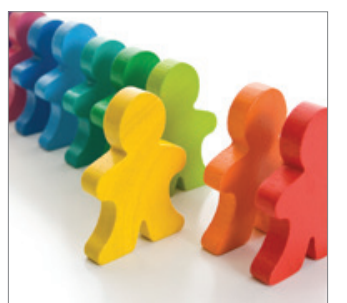

Autism

Research and Treatment
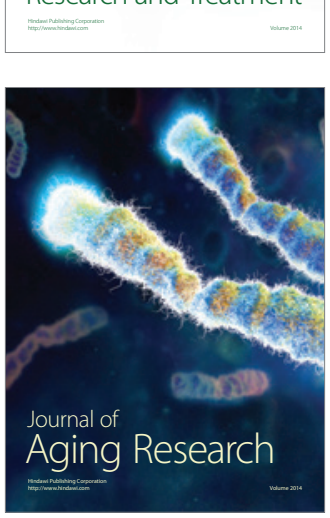
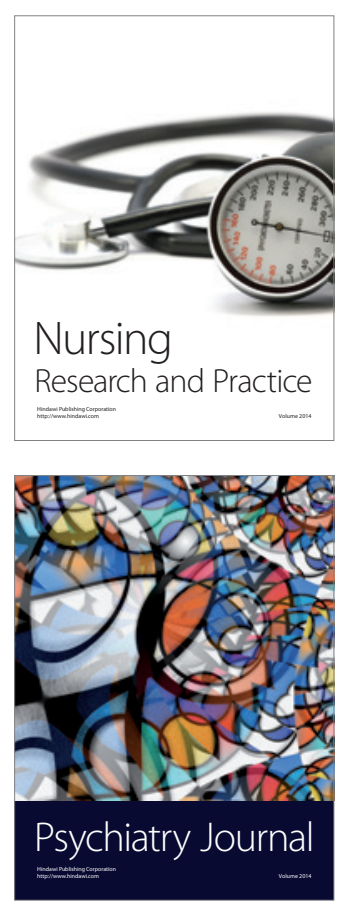
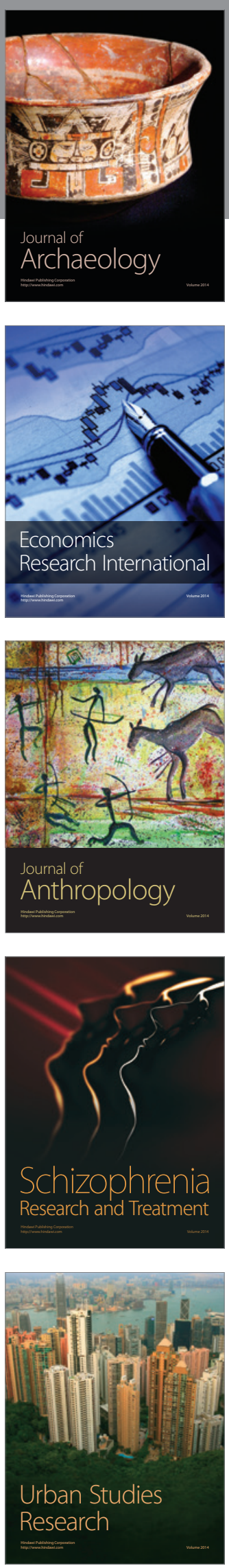